\title{
The spirituality in the process of treatment for oncologics patients
}

\author{
Dias, W.L.R', Vasconcelos, A.M.B², Santos, O.S³, Melo, T.R.C4, Costa, G.S5, Silva, C.C6 \\ 1,2,3,4,5Acadêmicos do Curso de Bacharelado em Enfermagem - Asces-Unita. E6Docente do \\ Curso de Bacharelado em Enfermagem - Asces-Unita
}

\begin{abstract}
Introduction: Neoplasms are a kind of the principal chronic and degenerative diseases that more causes morbidity and death in the world, being indispensable the attempt to reduce the torment, thus, the spirituality comes like a support that promotes a better quality of life. Objectives: Describe like spirituality can to influence in the treatment of oncologics patient. Methodology: The present study is a revision of integrative role, whose reviewed articles were captured through database analysis: BDENF, LILACS and SciELO. The descriptors utilized were: Spirituality, Cancer, Oncology and Patient. This analysis were realized on september $22 \mathrm{nd}$ and $23^{r} \mathrm{t}, 2017$; the criterions of the included were published articles in portuguese and english, in 2010 to 2016, being excluded all that haven't adequation at thematic of study. By means of the criterions defined were found 124 publisheds, but, only 8 articles met the criterions of the principal objective. Results and Discussions: The oncologic diagnostic is seen in the contemporary society like incurable, although of exist many ways of treatment, this ascend the mental disorder in the patients and family that searches in the spirituality a protector paper against this morbidity. In the search of this spiritual care, scientific evidences shows that it has influenced the clinic and disease course, increasing thus the quality of life in the patient. Conclusion: Not is possible treat a singly disease, is important that the patient been integrated in the treatment with aspects biopsychosocial, spiritual and ecologic for that has a improvement or cure. With this, can accentuate that the spirituality is indispensable for a good diagnostic.

${ }^{*}$ Correspondence to Author:

Dias, W.L.R

Acadêmicos do Curso de Bacharelado em Enfermagem - Asces-Unita

How to cite this article:

Dias, W.L.R, Vasconcelos, A.M.B, Santos, O.S, Melo, T.R.C, Costa, G.S5, Silva, C.C.The spirituality in the process of treatment for oncologics patients.International Journal of Pain Research and Treatment, 2018, 1:3

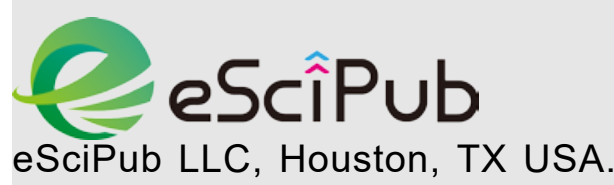

Website: http://escipub.com/
\end{abstract}

Keywords: Cancer; Spirituality; Patient; Oncology 